\title{
Review on China-Lesotho International Cooperation Platforms in the Background of Belt and Road Initiative
}

\author{
Matete Mahao \\ School of Overseas Education \\ Yunnan University of Finance and Economics \\ Kunming, China \\ Ranthomeng11@gmail.com
}

\author{
Ning Yan* \\ International School of Education \\ Yunnan University of Finance and Economics \\ Kunming, China \\ Ningyan68@126.com
}

\begin{abstract}
The Kingdom of Lesotho like other developing countries participates in a number of international cooperation platforms. These kinds of platforms occur both at bilateral and multilateral parameters geared towards social development and economic growth as well as International Trade and support. China has diplomatic and international cooperation with Lesotho in a number of platforms like China-Lesotho Cooperation, Forum on China Africa Cooperation and the African Union Agenda 2063, which China has committed itself to support the same strategy, in which Lesotho is a direct stakeholder as a member state in African Union. These platforms in relation to China-Lesotho Cooperation happen under the direct impetus of the Belt and Road Initiative (BRI).
\end{abstract}

Literature Review Methodology combined with Case Study Methodology using Snowball Sampling was conducted to have an in-depth collection of both the Primary and Secondary Data relating thereto this study. These methodologies were conducted to conduct a review on the China-Lesotho International Cooperation Platforms under BRI and Inductive Data Analysis Approach was used and, summary and conclusion thereof were made to give a holistic view of these platforms on advancing the bilateral relationships between the two countries

Keywords: BRI, A.U. Agenda 2063, FOCAC, China-Lesotho Cooperation

\section{INTRODUCTION}

Lesotho and the People's Republic of China have a long history of bilateral relations that are marked by a number of activities that include business, diplomatic support, development projects, social and cultural exchange programs and politics. These activities occurred under a number of international cooperation platforms involving both countries and hence enhancing the stronger ties between the two under the background of the Belt and Road Initiative. The aforementioned cooperation platforms and other factors forming content of this paper shall be deliberated on with a view to furnish the reader with the general picture of this cooperation.

\section{LITERATURE REVIEW}

As it had been stated, the Literature Review Methodology was employed to conduct a review on the secondary data relating thereto China-Lesotho International Cooperation Platforms under the Belt and Road Initiative. First the literature will focus on the Belt and Road Initiative which is the foundation upon which China and Lesotho Bilateral Cooperation Platforms are based.

\section{A. THE BELT AND ROAD INITIATIVE}

In 2013, Chinese President Xi Jinping announced plans to build a Silk Road Economic Belt and a 21st-Century Maritime Silk Road, previously known as 'One Belt, One Road' which is the current Belt and Road Initiative. The BRI has for its object to encourage connectivity, economic flow, job opportunities, investment and consumption, cultural exchanges and the spirit of regional cooperation between Asia, Europe and Africa by jointly building trade routes emulating the ancient Silk Road.

The Silk Road Economic Belt connects China, Central Asia Russia and Europe, and the 21st Century Maritime Silk Road moves along China's coast towards Europe in one direction and through the South China Sea and the South Pacific. The BRI overland path will leverage existing international transport routes and key economic industrial parks as springboards for cooperation, while the sea route aims to build transport routes bridging major sea ports across the BRI project [13]

According to Wikipedia BRI has for its purpose:

To construct a unified large market and make full use of both international and domestic markets, through cultural exchange and integration, to enhance mutual understanding and trust of member nations, ending up in an innovative pattern with capital inflows, talent pool, and technology database.

Alongside the BRI is China's plan to build 50 Special Economic Zones (SEZs) that are modeled after the Shenzhen Special Economic Zone launched by China in 1980 under its economic forums [3]. Chinese leaders are committed to restructure the economy to dodge the so-called middle-income trap, whereby almost 90percent of middle-income countries are plagued since 1960 [3]. In this phenomenon wages rise and

*Corresponding author 
quality of life improves alongside the rising low-skilled manufacturing and countries struggling to then shift to production of high-value goods and services. According to Zhang [Cited in 3] BRI will provide new import and export options thereby creating new production chains that will spearhead the development of the Chinese economy. This argument is supported by [13] below.

From the following literature, evidence can be seen that BRI has already played pivotal role in global development on the following areas: First, BRI has opened a new era for international cooperation and has boosted confidence in it; Second, BRI has created new impetus and potentials for global growth; and Third, BRI provides a new platform fostering closer ties between countries [13]. The nature, extent and the intensity of BRI makes it the umbrella platform that China participates in and fosters the development, and efficient and effective performance of these other international platforms and projects in which China participates and directly supports in terms of infrastructure projects, expertise and financial support. Note. From the Author.

Table on Chinese Trade with countries along BRI corridors

\begin{tabular}{|l|l|}
\hline PERIOD & Trade Volume \\
\hline 2013 to 2017 & Grew beyond previous \$ 6,975 billion \\
\hline 2014 to 2019 & Exceeded \$ 6 trillions \\
\hline 2019 & Estimated around \$ 200 billion \\
\hline Sourced from, Stratfor 2019.
\end{tabular}

Under this cooperation the Kingdom of Lesotho is not an exception and has already started to benefit directly from this initiative with the evidence of the platforms to be delivered on and the recently launched China-funded Ha-Mpiti to Sehlabathebe $91 \mathrm{~km}$ Road Project at the budget cost of 128 million U.S. Dollars (from Chinese concessional loan) with the potential to create more than 300 employment opportunities through local procurement and contracting [8].

However positive the Belt and Road Initiative appears, there are some critics that it is, but only a medium through which China strategically expands its global political influence and power and that the initiative's philosophy of preaching sustainable energy developments seems to meets some odds with projects whereby Chinese banks under the initiative have funded as much as 140 coal plants worldwide.

Despite the aforementioned critics, based on the number of infrastructure international projects China has helped the countries under the BRI and the number of countries joining the initiative, and Africa and Lesotho in particular, as well as China's commitment in this initiative, it becomes evident that this initiative is the world trade and business cooperation mother platform. The Belt and Road Initiative is the world's leverage for international cooperation and support and is growing steadily in its pace connecting countries through road infrastructure and boosting countries' economies and social development. For the Kingdom of Lesotho the initiative has in particular done a lot of positive impact though there is a problem with limited literature sources in this regard.

\section{B. THE AFRICAN UNION AGENDA 2063}

As Africa commits to its social and economic development strategy called African Union Agenda 2063 fostered by the ideals of Pan Africanism and vision of Africa Renaissance,
China does not alienate itself from this initiative intended to pursue 7 aspirations that include:

A Prosperous Africa based on Inclusive Growth and Sustainable Development; An Integrated Continent Politically United based on the Ideals of Pan Africanism and Vision of Africa Renaissance; An Africa of Good Governance, Democracy, Respect for Human Rights, Justice and the Rule of Law; Peaceful and Secure Africa; Africa with a strong Cultural Identity, Common Heritage, Values and Ethics; Africa whose Development is People Driven, relying on the Potential offered by African People, especially its Women and Youth, and Caring for Children; An Africa as a Strong, United, Resilient and Influential Player and Partner.

The People's Republic of China has fully committed itself to partake in this noble development initiative through facilitating its success with the support of the Belt and Road Initiative and other support structures like the development projects and International Scholarships for Developing Countries in which the Kingdom of Lesotho is one of the key beneficiaries as a diplomatic partner with China and a member state in the African Union [6]. Under China's commitment to support the A.U. Agenda 2063 a number of action oriented support activities and projects have already occurred under the background of BRI under Program for Infrastructure Development in Africa (PIDA).

In a paper with the title 'China's Belt and Road Initiative: linkages with the African Union's Agenda 2063 in historical perspective' [11] argues that BRI has the direct alignment with A.U. Agenda 2063 on Aspirations 2, 4 and 5. They further argue that BRI proofs to have developmental implications for Africa in terms of industrialization and infrastructure rolling thereby boosting intra-continental trade, the African Peace and Security Architecture and intra-continental people-to-people exchange. The cited paper then concluded that for reciprocal benefit of this alignment there should be concerted efforts on both Africa and China with a view to synchronize infrastructure with socio-economic/demographic realities.

It is therefore imperative to deduce that the BRI and the A.U. Agenda 2063 are strong cooperation initiatives/ strategies that have a brighter future with massive impact on both China and African social growth and economic development based on mutual support and long sighted vision for better future of the two stakeholders behind these two initiative/programs. This alignment of BRI with A.U. Agenda 2063 creates a common vision and strategy for mutual development cooperation between China and Africa, and the Kingdom of Lesotho in particular.

\section{THE FORUM ON CHINA-AFRICA COOPERATION}

The Forum on China-Africa Cooperation (FOCAC) previously known as China-Africa Forums (CAFs) is an official multilateral forum between the People's Republic of China and African States (exclusive of Eswatini which recognizes Taiwan and as such has no diplomatic relations with the PRC to date) under the background of BRI. Almost 3 FOCAC Summits have been held to date with the first summit being held in 2006, Beijing, China, the second summit in 2015, Johannesburg, South Africa and the third summit in 2018, 
Beijing, China [5 \& 15]. Based on its characteristics, FOCAC is a platform for collective consultation and dialogue and a cooperation mechanism between the developing countries that falls into the category of South-South cooperation that is directly fostered by the BRI.

Based on the perspective of [7] China through FOCAC offers Africa what they call a 'unique package of economic, political and security inducements ' that include: Targeted debt relief; Participation in peace-keeping operations in places such as Liberia, DRC and Sudan; Cheap loans linked to infrastructure development; Political junkets for African leaders to Beijing; Support for Africa in global forums; Competitive military deals; Collaborative projects on 'traditional medicines; Political 'non-interference' in the internal policies of African countries; The promotion of 'southsouth' linkages; and The establishment of parallel funding agencies to institutions like the IMF and the World Bank. This is based on the key tenets of the five principles upon which China's foreign policy is proceeds.

In 2018 FOCAC summit in Beijing declared an Action Plan stating Africa as an important partner in the BRI cooperation [7].

Following is a table on FOCAC Ministerial Conferences.

Note. From the Author.

\begin{tabular}{|c|c|c|}
\hline $\begin{array}{c}\text { MINISTERIAL } \\
\text { CONFERENCES }\end{array}$ & VENUE & $\begin{array}{l}\text { YEAR } \\
\end{array}$ \\
\hline $1^{15}$ ministerial conference & beijing, china & 10 to 12 october 2000 \\
\hline $2^{\text {nut }}$ ministerial conference & addis ababa, ethiopia & 15 to 16 December 2003 \\
\hline $3^{\text {tut }}$ ministerial conference & Beijing, china & 3 to 5 November 3006 \\
\hline $4^{\text {tII }}$ ministerial conference & share-sheikh, Egypt & 8 to 9 November 2009 \\
\hline $5^{\mathrm{It1}}$ ministerial conference & BEIJING, CHINA & 19 TO 20 JULY 2012 \\
\hline
\end{tabular}

table 2. focac summits

\begin{tabular}{|c|c|c|}
\hline SUMMIT & VENUE & YEAR \\
\hline $1^{\mathrm{ST}}$ FOCAC SUMMIT & BEIJING, CHINA & 3 TO 5 NOVEMBER 2006 \\
\hline $2^{\mathrm{ND}}$ FOCAC SUMMIT & JOHANNESBURG, SOUTH AFRICA & 4 TO 5 DECEMBER 2015 \\
\hline $3^{\mathrm{RD}}$ FOCAC SUMMIT & BEIJING, CHINA & EARLY SEPTEMBER 2018 \\
\hline
\end{tabular}

Table 3. China Export from 2001 to 2019: Africa: Lesotho.

\begin{tabular}{|c|c|c|c|}
\hline Previous & Recent & Frequency & Range \\
\hline 6.664 & 6.246 & Monthly & $\begin{array}{c}\text { Jan 2001-Aug 2019 } \\
\text { Updated on 23 Sept } \\
\text { July 2019 }\end{array}$ \\
\hline
\end{tabular}

Based on the table above it can be seen that there have been ups and downs in the China Export across the years, but the strength of the performance is rather steady.
It is worth mentioning that the proposal from the Kingdom of Lesotho for the recently completed New Lesotho Statehouse Project was delivered in the sixth FOCAC summit held in 2015 in Johannesburg South Africa. The Budget Cost for this project was 79,000.000.00 RMB.

There was a case study conducted on this project as the most recently completed project under FOCAC under BRI impetus, where the following Key Factors Influencing the Effectiveness of Initiation and Planning Integration on the Lesotho Public Sector Projects were identified: The Feasibility Study and Environmental Impact Assessment Study; the Project Charter; Stakeholders Involvement and Management; Project Plan and Assumptions; Project Risk Management Plan; Work Breakdown Structure and Critical Path Method; Communication Plan; Procurement Plan; the Project Manager's Experience and Skills; Project Supervision by Build and Design Services ; the two countries Support and Commitment to the project; Involvement of Technical Teams (Design Teams) from both Partnering countries and their Coordination.

However there are some geographical, distance, cultural and economic differences challenges between China and African countries, but the reciprocal commitment of the two coupled with continuous conferences shall overcome those barriers aforementioned. These factors are the ones that contribute to the fluctuations in the on the imports and exports performance depicted in the two tables. But as stated there are efforts to overcome this situation, and the cooperation is steadily growing despite those challenges.

\section{CHINA-LESOTHO COOPERATION}

The China-Lesotho Cooperation denotes the bilateral relationship between the Kingdom of Lesotho and the People's Republic of China. Mutual relations between these two date back to the rule of Prime Minister Leabua Jonathan under the Kingship of King Moshoeshoe II. These relations culminated with the diplomatic visit of Prime Minister Leabua Jonathan to China in 1983, which was subsequently followed by the state visit by King Moshoeshoe II in 1985 [2].

These relations are still going on to date with more deepening spirit of common economic growth and trade that happen at a win-win spirit while at the same time both countries continue to respect each other's sovereignty. There are a number of development benefits that Lesotho and China have reciprocally enjoyed and are still enjoying in these relations. To mention just a few, they count from, but are not limited to the Radio and Television Network Expansion Project, Solar Energy Demonstration Project, Technical Cooperation Project of Land use and Physical Planning, the New Lesotho State Library Project, the Manthabiseng Convention Centre Project, the recently launched $91 \mathrm{~km}$ road Project from HaMpiti to Sehlabathebe in the Qacha's Nek District under BRI, the New Lesotho Parliament Project, the China-Lesotho Friendship Academy and the recently completed new Lesotho Statehouse Project, the Chinese Enterprise and Textile Investment in Lesotho, China Exports to Lesotho, China Import of wool and mohair from Lesotho [13]. Note. From Author. 
Table 4. China Funded Projects in Lesotho under International Platforms in the background of BRI

\begin{tabular}{|c|c|c|c|}
\hline PROJECT NAME & PROJECT PLACE & YEAR & $\begin{array}{l}\text { PROJECT BUDGET } \\
\text { COST }\end{array}$ \\
\hline $\begin{array}{l}\begin{array}{l}\text { Manthabiseng } \\
\text { Convention } \\
\text { Project }\end{array} \quad \text { Centre } \\
\end{array}$ & Maseru District & 1997 & Missing \\
\hline $\begin{array}{llr}\text { New } & \text { Lesotho } & \text { State } \\
\text { Library } & \text { and } & \text { Archives } \\
\text { Project }\end{array}$ & Maseru District & 2004 & $\begin{array}{ll}\text { Loan-RMB } & \\
25,300,000.00 & \text { around } \\
\text { USD 3,603,064 } & \\
\end{array}$ \\
\hline $\begin{array}{ll}\text { China-Lesotho } & \\
\text { Friendship } & \text { Middle } \\
\text { School } & \\
\end{array}$ & Berea District & 2016 & Grant (Cost missing) \\
\hline $\begin{array}{l}\text { New Lesotho Parliament } \\
\text { Project }\end{array}$ & Maseru District & 2007 & $\begin{array}{lll}\begin{array}{l}\text { USD } \\
\text { million }\end{array} & 12, & 622,227 \\
\end{array}$ \\
\hline $\begin{array}{l}\text { Ha-Mpiti to Sehlaba- } \\
\text { Thebe Road Project }\end{array}$ & Qacha's Nek District & 2018 & USD 128 million \\
\hline
\end{tabular}

Both countries have committed themselves to continuous mutual cooperation in areas of Economy, Trade and Cultural Exchange under the guiding spirit of win-win benefit. At the background of this bilateral cooperation between China and Lesotho and their related platforms lies the Belt and Road Initiative as the mother platform under which the cooperation referred to happens [10 \& 12]. In the Article Belt and Road Cooperation: Advancing China-Lesotho Cooperation with New Impetus Mr. Song Changqing, Charge d'Affairs ad interim of the Embassy of the People's Republic of China in the Kingdom of Lesotho was cited indicating that " Over the years, the China-Lesotho capacity building cooperation and the people-to-people exchanges are also growing from strength to strength" [12].

According to (10) China in its bilateral cooperation with Lesotho is guided by the following principles:

That China shall not impose its own will on the Kingdom of Lesotho.

China puts emphasis on "showing the other how to fish instead of giving the other the fish" with an object to enhance the capacity of Lesotho to be self-reliant and to have sustainable development.

China emphasizes on the tactic of "building nest to attract phoenix" through assisting the Kingdom of Lesotho to develop infrastructure which is key foundation for economic growth

China never makes empty promises and is result-oriented in its cooperation with Lesotho.

The issues of international trade between the two countries are also taking pace with the developments in the platforms connecting the two, though there are some challenges and ups and downs that will be seen in the table to follow.

The following table shows the trade factors trends between China and Lesotho.

Note: From Author.

Table 5. China-Lesotho Trade Factors Trends.

\begin{tabular}{|c|c|c|}
\hline \multirow{2}{*}{$\begin{array}{c}\text { TRADE VOLUME BETWEEN } \\
\text { CHINA AND LESOTHO }\end{array}$} & 2013 & 100 Million USD \\
\cline { 2 - 3 } & 2017 & 86 Million USD \\
\hline $\begin{array}{c}\text { PERCENTAGE INCREASE in } \\
\text { Trade Volume }\end{array}$ & 2013 & $3.5 \%$ \\
\hline $\begin{array}{c}\text { IMPORT VOLUME-China Import } \\
\text { from Lesotho }\end{array}$ & 2012 & Increased by 147.6\% \\
\cline { 2 - 3 } & 2017 & 25 Million USD \\
\hline $\begin{array}{c}\text { EXPORT VOLUME-China Export } \\
\text { to Lesotho }\end{array}$ & 2014 & 11.36 Million USD \\
\hline $\begin{array}{c}\text { CHINA INVESTMENT } \\
\text { ANNUAL TRADE VOLUME } \\
\text { INCREASE }\end{array}$ & 2013 & $15.9 \%$ \\
\hline $\begin{array}{c}\text { ZERO Tariff Treatment granted to } \\
\text { Lesotho Commodities }\end{array}$ & 2017 & $95 \%$ \\
\cline { 2 - 3 } & 2013 onwards increase to & $97 \%$ \\
\hline
\end{tabular}

Despite the economic differences, geographic distance, political differences, topographic structure of Lesotho, the two countries continue to be life partners in development based on mutual and political support, and win-win cooperation whereby respect for each other's sovereignty is very important. There are a number of the projects and other benefits in pipeline from China funding which are still to be carried on like the New state of the art Hospital and Eye Clinic in Maseru City, Fire Fighting Centre, Agricultural Products Storage and Trading Centre and Waste and Garbage Treatment Facility [8]. These are therefore clear indicators of steady growth in the cooperation between the two countries, not forgetting China's commitment to afford Lesotho $97 \%$ zero tariff treatment.

\section{METHODOLOGY}

As stated previously this study used combination of two research methodologies being the Literature Review Methodology for collection of Secondary Data relating to the Belt and Road Initiative and the other International Platforms on China-Lesotho Cooperation under BRI. The literature review involved the findings from the literature by other writers who have previously written about the same topics.

The second methodology that was employed was the Case Study Methodology using the Snowball Sampling Method whereby the Expert Interviews and Questionnaires were used for Primary Data collection using the Likert Scale in the case study on the New Lesotho Statehouse Project under FOCAC. The case study methodology is used to inquire into the contemporary phenomenon in the context of real life, especially in the ambiguity between the phenomenon and the context, and is used where there is researcher's limited or no knowledge about the situation or organization, and has little or no control over the events.

Since the researcher had little information about the New Lesotho Statehouse Project, and had no control over the phenomenon, Case Study was utilized to study the project in question. According to Qualitative Research in Snowball sampling the researcher uses contacts, referrals and informants for selection of the sample.

Because of scattered distribution of the individuals among the different units, sections, departments and ministries involved in Lesotho Public Sector Projects, it was very difficult to draw a well-structured sample and as a result Snowball was the best-fit method in this particular scientific inquiry.

Inductive Data Analysis Approach was used for analysis of both the primary and secondary data in order to have a wider perspective and to develop an in-depth understanding of the phenomenon of the China-Lesotho Cooperation Platforms under the BRI. Data analysis is the process of inspecting, cleansing, transforming, and modeling of data with the goal of discovering useful information, informing conclusions, and supporting decision-making [2]. As it has been mentioned, the data analysis method that was utilized was Inductive Data Analysis Method.

The Inductive Approach had been chosen for this analysis as the researcher had limited knowledge about the research phenomenon at the time of inquiry. 


\section{DISCUSSIONS}

Both secondary and primary data was collected in relation to China-Lesotho International Cooperation Platforms under Belt and Road Initiative with a view to help the author with an insight into the platforms, their nature and extent so as to help the author to make a well informed review that is scientifically and logically backed. According to the evidence of the literature reviewed it was found that in overall there are basically three international platforms on China-Lesotho International Cooperation under the impetus of the Belt and Road Initiative.

On average the platforms are a great success for both countries under this bilateral cooperation yielding a lot of reciprocal benefits for both partners. This however does not alienate the fact that 'there is no road without potholes' as the saying goes, and as such it is the case with the cooperation platforms under this study as it will be discussed in this section of the paper.

The nature, extent and the intensity of BRI makes it the umbrella platform that China participates in and fosters the development, and efficient and effective performance of these other international platforms and projects in which China participates and directly supports in terms of infrastructure projects, expertise and financial support.

However there are some critics that Belt and Road Initiative is, but only a medium through which China strategically expands its global political influence and power and that the initiative's philosophy of preaching sustainable energy developments seems to meets some odds with projects.

Despite the aforementioned critics, based on the number of infrastructure international projects in which China has helped the countries under the BRI and the number of countries joining the initiative, and Africa and Lesotho in particular, as well as China's commitment in this initiative, it becomes evident that this initiative is the world trade and business cooperation mother platform. The Belt and Road Initiative is the world's leverage for international cooperation and support and is growing steadily in its pace connecting countries through road infrastructure and boosting countries' economies and social development. For the Kingdom of Lesotho the initiative has in particular done a lot of positive impact though there is a problem with limited literature sources in this regard.

It is therefore imperative to deduce that the BRI and the A.U. Agenda 2063 are strong cooperation initiatives/ strategies that have a brighter future with massive impact on both China and African social growth and economic development based on mutual support and long sighted vision for better future of the two stakeholders behind these two initiative/programs. This alignment of BRI with A.U. Agenda 2063 creates a common vision and strategy for mutual development cooperation between China and Africa, and the Kingdom of Lesotho in particular.

However there are some geographical, distance, cultural and economic differences challenges between China and African countries, but the reciprocal commitment of the two coupled with continuous conferences shall overcome those barriers aforementioned.
Despite the economic differences, geographic distance, political differences, topographic structure of Lesotho, the two countries continue to be life partners in development based on mutual and political support, and win-win cooperation whereby respect for each other's sovereignty is very important. There are a number of the projects and other benefits in pipeline from China funding which are still to be carried on like the New state of the art Hospital and Eye Clinic in Maseru City, Fire Fighting Centre, Agricultural Products Storage and Trading Centre, and Waste and Garbage Treatment Facility. These are therefore clear indicators of steady growth in the cooperation between the two countries, not forgetting China's commitment to afford Lesotho $97 \%$ zero tariff treatment.

The following strengths have been identified in these platforms for their success and sustainability. BRI being the mother platform for international cooperation between countries and China it has the objectives that serve as the key strengths for these other platforms. The objectives referred to are the following: 'To construct a unified large market and make full use of both international and domestic markets, through cultural exchange and integration, to enhance mutual understanding and trust of member nations, ending up in an innovative pattern with capital inflows, talent pool, and technology database'. Further strengths are on synchrony between BRI objectives and AU Agenda 2063, in particular aspirations 2, 4 and 5 as well as objectives of Lesotho National Strategic Development Plan 2018/19-2022/23. The commitment that is also seen from the member states in the BRI as well as the commitment and monitoring by the World Bank form part of the strong support base for the success and sustainability of the platforms and their related projects and programs. The other factor for the success referred to can be perceived from the long standing history of the bilateral relations between The Kingdom of Lesotho and the People's Republic of China which dates as far back as early 80s. The role that is played by the summits and the conferences held internationally that facilitate the sustainability of these cooperation platforms also cannot be overlooked.

Alongside the aforementioned strengths are the numerous reciprocal benefits that have already been enjoyed by China and Lesotho as well as other member states in the BRI. The benefits of social and cultural exchange have been evidenced in the history of these platforms, international business and trade in terms or imports and exports have also been seen as well as social development and economic growth through mutual support. Peace, security and political support have also been evidenced in China's Peace Keeping support in some of African countries like DRC. Other benefits include infrastructure and industrialization developments that are happening in Lesotho and other African countries under the support of Chinese Government through BRI, FOCAC and China-Lesotho Cooperation, not alienating the BRI and FOCAC facilitation of AU Agenda 2063 and the Lesotho National Strategic Development Plan 2018/19-2022/23.

According to the literature the following are very essential key factors for the success and sustainability of the international cooperation platforms under study in this paper: 
Good governance which covers issues of transparency, accountability, peace, rule of law, political will, well designed policy frameworks for international relations and international projects management. Continuity of government programs. Principle of non-interference as interference can spoil good international relations. Well-designed monitoring and evaluation mechanisms. Clearly articulated action plans.

Though the strengths and benefits are numerous to mention, this does not deny the fact that there are some gaps, flaws and limitations in these cooperation platforms and the literature itself. First there is lack of enabling infrastructure in most of the African countries, inclusive of Lesotho; there is lack of policy frameworks for international projects and some other issues related to international relations; political power tension between China and USA puts Lesotho in a vulnerable position of being suspended between the interests of the two funding giants; China being the donor and economic giant might possibly want to impose its interests as it is the sometimes the case with donors. The issues of market fluctuations as depicted in the tables pose a big threat to the stability and sustainability of the cooperation.

The main flaws, gaps and limitations identified in this literature is that there is inconsistency in statistical data that is even lacking consistent chronological order; there is lack of scientific research backed data in relation to China-Lesotho International Cooperation. Some data on some of the budget costs for the China funded projects in Lesotho is lacking, and also there is no data explaining the causes of the fluctuations in the import and export between China and Lesotho, and China and Africa and how such causes or phenomenon is going to be addressed, hence a serious need to conduct further research in the phenomenon in order to develop a scientifically backed understanding of the status quo of China-Lesotho International Cooperation Platforms under the background of Belt and Road Initiative, as well as to develop the most appropriate policy frameworks for facilitation of the success and sustainability of this bilateral cooperation platforms and their related projects and programs.

\section{SUMMARY AND CONCLUSION}

China-Lesotho Cooperation has a long history of socioeconomic support ranging from trade, skills sharing and development projects under a number of both bilateral and multilateral platforms. However the projects under these kinds of cooperation need carefully managed Project Initiation and Planning Integration Management which is facilitated among other key factors by carefully conducted Feasibility Study, Stakeholder Management, carefully designed Project Risk Management Plan, carefully Coordinated Project Team and full key Stakeholders Support and Commitment. The cooperation between China and Lesotho is evidently growing steadily under the platforms aforementioned with the impetus the Belt and Road Initiative, however there have been some challenges like the ups and downs in the Trade, Business, Import and Export fluctuations as seen in the graph and tables.

\section{RECOMMENDATIONS}

The following recommendations are made for future excellence in management of the Public Sector International Projects under China-Lesotho Cooperation under BRI Impetus; Projects be need driven and very detailed Feasibility and Environmental Impact Assessment Studies be done to ensure alignment of the projects with the Client's needs and to meet the national geographic situation of the countries as well as to ensure environmental safety; All stakeholders to the projects be involved; There be establishment of Team of Experts from both key Stakeholders (countries) to form one Integrated Technical Experts Team; Clear Policy Frameworks be developed for these kinds of projects.

At theoretical level there should be more research on the Best Frameworks for implementation of Lesotho Public Sector International Projects; and also the research on Key Enabling Factors for Successful International Business and Trade Cooperation between China and Lesotho be conducted, and finally that further scientific research be done on the status and performance of international projects under China-Lesotho Cooperation Platforms under the Belt and Road Initiative as well as the projects done directly under the BRI itself.

\section{ACKNOWLEDGMENT}

Humanities and Social Science Planning Fund of Ministry of Education of China (17YJA850011)

\section{REFERENCES}

[1] China Export: Africa: Lesotho. Available from: https://www-ceicdatacom.cdn.am

[2]China-Lesotho Relations. Available from: https://en.m.wikipedia.org

[3] China's Massive Belt and Road Initiative: Council on Foreign Relations. 2019 .

[4] Chronology of China's Belt and Road Initiative, English. GOV.CN: The State Councils, The People's Republic of China.

[5] Enuka, C, 2010, the Forum on China-Africa Cooperation (FOCAC)-BZU

[6] Honglie, Z \& Tesfaye, N, 2018, 'Alignment of Belt and Road Initiative with Africa Agenda 2063', Paper presented at Asian B\&R Conference on International Business Cooperation, The Third International Symposium 2018- Kunming, China.

[7] Institute of Developing Economies Japan External Trade Organization. Available from: http://www.ide.go.jp

[8] Lesotho Launches China - funded Mpiti to Sehlabathebe Road Project. Available from: https://africa.cgtn.com

[9] Lee, J. \& Jinghan, Z., 2019, Understanding China's Belt and Road Initiative: beyond 'grand strategy' to state transformation analysis, Third World Quarterly, 40:8, 1415-1439,DOI:10.1080/01436597.2018.1559046

[10] Move Forward China-Lesotho Cooperation with FOCAC. Beijing Summit, 2018.

[11] Ndzendze, B. 2019, China's belt and road initiative: linkages with the African Union's Agenda 2063 in historical perspective. Available from: http://www.tandfonline.com>full.

[12] Recent Development between China and Lesotho, 2013; Available from, English.mofcom.gov.cn

[13] Song, C, 2019, Belt and Road Cooperation: Advancing China-Lesotho Cooperation with New Impetus. Available at: 1s.chinaembassy.org/eng/sgdt/t1656618.htm

[14] www.worldpoliticsreview.com2019

[15] Zeng, A \& Shu, Z, Origin, Achievements, and Prospects of the Forum on China-Africa Cooperation. 